\title{
Use of Electronic Media for the Promotion of Notaries According to the Notary Code of Ethics
}

\author{
Puteri Chintami Oktavianti \\ Faculty of Law, Universitas Tanjungpura, Indonesia \\ nanaminatsumi.nn@gmail.com
}

\begin{abstract}
The purpose of this study is to determine the problems that arise in the use of electronic media for the promotion of notaries according to the notary code of ethics. The research method used is that this type of research is juridical normative, which refers to the norms of written law, either as outlined in the form of regulations or in the form of literature. The approach used is a conceptual approach and a statutory approach. The analysis is descriptive qualitative, which collects and selects legal material according to the problem under study, then describes it so that it produces a picture or conclusion that matches the actual situation so that it is able to answer all existing problems. The results show that the existence of a promotion prohibition for notaries is based on the fact that a notary as a position that provides services to the community requires the trust of the people it serves, and the notary's existence is not for the personal benefit of the person appointed, so that the notary must uphold the nobility of his dignity. In promotions that are informative and reminders, it is permissible to, among others, provide information and knowledge about legal issues; case review of legal problems in the world of notary; examples of notary deeds.
\end{abstract}

Keywords

electronic media; notary bond promotion, notary code of ethics

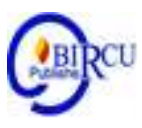

\section{Introduction}

With the magnitude of the duties and powers of a notary, the notary must remain obedient to the laws, regulations and ethics that apply when carrying out his professional duties, because the notary position is a trusted position. The purpose of the trust office is for the notary to behave properly. The notary is obliged to keep everything he believes. Notary is a legal profession that is noble in nature and very closely related to society. The actions of a notary can be used as a legal basis for a person's property, rights and obligations, or become someone's burden (Cahyanti, 2018).

Notaries can only carry out their duties in one office, and may not use intermediaries or promote them in any form. It must also provide services to disadvantaged groups of society free of charge. Notary ethics is regulated in the "Regulation of Notary Position (UUJN)" and the Code of Ethics for the Position of Notary. Notaries must maintain a good personality both inside and outside their work, as well as maintaining the dignity of the notary (Diani \& Agus, 2019).

With the influence of information technology and electronic transactions in Indonesia, this causes people's needs to always be dynamic. Therefore, national development is a continuous and sustainable process and must always respond to various dynamics that occur in society. The first thing that the government must do in facing the 
globalization of technology and information is to create a legal basis to uphold the principle of legal certainty so that it becomes the basis for everyone to follow the legality of technology and information developments.

For notaries, advances in information and technology provide maximum opportunities for notaries to improve their thinking and abilities in the field of information technology in the best and responsible way. Notaries use a lot of electronic media, such as wordpress, blogspot, multiple, scribd, and even social networking pages, such as myspace, facebook, facebook Indonesia, yahoo group, twitter, netlog. Almost all notaries who have a blog or social network page include their name and title (Rachmawati \& Fadli, 2019).

Many of these pages provide dedicated discussion rooms where you can get live feedback. The presence of blogs has very diverse functions, ranging from diaries to publication media, as well as the function of interacting with visitors, so they can comment on the content of published articles. In fact, most blogs owned by notaries provide space for discussion and legal advice, especially in the field of civil law, regarding the procedures for formulating contracts related to filling details.

Not a few of these pages provide a special discussion space that is immediately responded to. But in general, it aims to bring in as many potential visitors as possible, with the hope that more people will be able to see the information provided on the blog. So that the general public can see the information provided on the blog. In terms of opportunities, the general public will know more about the products and services offered, or at least know about the notary's profile. Even further, it could be interested in making deeds to the notary concerned.

There are so many writings from notaries on blogs that include their name and position, even in the main menu accompanied by consultation / question and answer facilities. Even though there is a prohibition for notaries to carry out self-publication, either individually or collectively by including their name and position using print and / or electronic media in the form of advertisements, congratulations, condolences, gratitude, marketing activities, sponsorship activities either. in the social, religious, and sports fields.

Suhrawardi (2008) states that with the advancement of the times and science and technology, the rules for notary promotion through publication media regarding the standard rules prohibiting notaries from using print / electronic media facilities need to be amended in the UUJN concerning Notary Promotion through print / electronic media (Article 4 section 3 Notary Code of Ethics). Based on the description above, the authors wish to conduct research on problems that arise in the use of electronic media for the promotion of notaries according to the notary code of ethics.

\section{Research Methods}

The type of research used is normative legal research which refers to statutory legal norms, which are submitted either in the form of statutory regulations or in the form of literature. The method used is a conceptual method. The analysis used is descriptive and qualitative, namely collecting and selecting legal materials based on the questions studied; then describe it to draw conclusions that are in accordance with the actual situation, so as to be able to answer all the questions that exist. 


\section{Results and Discussion}

\subsection{Analysis of the Code of Ethics for the Position of Notary Public on Publication and Promotion of the Position of Notary Public}

The status of a notary public official is seen as a high status. Notary is a place where people and certain business groups get reliable legal advice. Recommendations made by a notary as part of legal advice are considered valid and fair for certain groups, because they are included in the notary's oath and legal products issued by the notary (Kie, 2011). Therefore, notaries must be relied on by their clients, society, and country. Notaries must also be independent, because notaries may not depend on any institution to run their business. If the other party claims to appoint a notary, he has the right to refuse (Ghansham Anand \& Kn, 2018).

A notary who is appointed to serve the public interest as a general official in the field of civil law cannot be the same as a position in an ordinary company. Notary services must follow the guidelines in the "Code of Ethics for the Position of Notary Public", because notaries are classified in the field of professional services that support high professional ethics. The wrong attitude towards notaries is ignoring the code of ethics and sacrificing the dignity of the notary. The motivation is not purely to serve the community, but is strong with elements of self-promotion. Even though the code of ethics is the corridor to save the profession of a noble and dignified notary position (Notaris, 2013).

Several parties who carry out publications and / or promotions as notaries in various media, both written and electronic media, to post the office address and telephone number of the notary's office are considered to be a form of notary publicity. So that supervision is needed by the Notary Honorary Board and the Notary Supervisory Council against parties who violate the Code of Ethics for the Notary's Position to prevent such violations in the future. The Indonesian Notary Association (INI) as a place that houses Indonesian notaries, can provide a decision or circular regarding the existence of an android application used by notaries without clear intent and purpose and imply invitations, promotions, persuasive words and the like. This is done so that notaries who have already used the Android application for promotion can withdraw their application from the Android application store. Apart from that, another effort is to make revisions to the notary position guidelines, namely the Code of Ethics for the Position of Notaries. This Code of Ethics is a rule used to determine the quality level of Indonesian notaries, so that it can be adjusted to the conditions of current technological advances.

A form of effort that can be made to enforce the Code of Ethics for the Position of Notaries against violations of the code of ethics, including particular rules or specific rules. Particular Rules or Specific Rules here are provisions that only apply specifically to any person holding the position of notary by applying the sanctions set out in the relevant Code of Ethics. In this case, it is Article 6 of the Code of Ethics for the Position of Notary which regulates sanctions for members of the association who violate the signs of the code of ethics. These sanctions can be in the form of reprimands, warnings, suspension (temporary dismissal) from association membership, onzetting (dismissal) from the association, and dishonorable dismissal from association membership (Dwi, 2013). 


\subsection{Forms of Violation Notary Conducts Job Promotion through Electronic Media According to the Code of Ethics}

Currently, there is rampant abuse of the legal profession, even in terms of position. The legal profession is used as a business activity, namely activities whose main purpose is to seek large profits. His main goal is to be paid, not to do his best. This often happens to notaries who carry out promotions and even advertise on the internet. Social networking pages that are used by notaries to socialize include Friendster, Facebook, Twitter, Netlog, and the Notary Services Blog. The various prohibitions on notary promotion using internet media include: (1) conducting promotions through electronic media or the internet, (2) conducting promotions through blogs that are used as an advertising or promotion event, (3) conducting promotions via the internet to promote legal services in the field notarial, and (4) doing promotions through advertisements at http://jasanotaris.blogdetik.com/.

Notary blog owners should not be allowed to compete unfairly and vilify their fellow notaries. This will be imitated by other notaries to carry out promotions through electronic media in a persuasive manner. This will also create a situation that is not conductive among fellow notaries, even it can lead to unfair competition in the future. ${ }^{1}$

\section{Prohibition}

\section{Article 4}

Notaries and other people who hold and carry out the positions of Notaries are prohibited from:

1. Has more than 1 (one) office, either branch offices or representative offices.

2. Put up a nameplate and / or writing that reads "Notary Public / Notary Office" outside the office environment.

3. Conducting publications or self-promotions, either individually or collectively, by including their names and titles, using print and / or electronic media, in the form of:
a. Advertisement;
b. Congratulations;
c. Condolences;
d. Thank-you note;
e. Marketing activities

f. Sponsor activities, both in the social, religious, and sports fields.

4. Cooperating with service bureaus / persons / legal entities which essentially act as intermediaries to seek or obtain clients.

5. Sign the deed whose Minut preparation process has been prepared by another party.

6. Send the client the Minuta to be signed

\subsection{Legal Sanctions Against Violations for Notaries Conducting Promotions Through} Electronic Media According to the Code of Ethics and Efforts for Notaries who are Sanctioned by the Code of Ethics

Sanctions are a means of punishment. Apart from punishment, the provisions of regulations or agreements must also be considered; if the agreement is not obeyed, sanctions are also interpreted as a means of coercion, namely as a means of punishment. According to Philipus M. Hadjon (2017), sanctions are a tool of power, public law used by authorities, and a response to violations of administrative law. Therefore, the element of sanctions as a tool of power is public law used by the authorities, which is a response to acts against the law.

\footnotetext{
${ }^{1}$ http://notarisinteraktif.wordpress.com/about/,
} 
In Indonesia, the enforcement of sanctions is not only in the form of law, but also in the form of other regulations, such as ministerial regulations or other forms regulated by law. Sanctions in Indonesia fall under various legal rules, such as obligations that must be included in every legal rule, as if the relevant legal rules cannot be implemented; or if sanctions are not stated, the rules will not be obeyed. If these rules are procedural (procedural law), there is no point in enforcing legal principles. These sanctions always follow legal rules which are mandatory legal rules.

Violation or breach of obligations stipulated in the rule of law can cause undesirable confusion in the relevant legal rules. This is in line with the sanctions function used to enforce the law against provisions which usually contain prohibitions or obligations. Therefore, sanctions are basically legal means, usually given when a legal obligation or prohibition is violated; whereas orders and prohibitions (geen verboden) which have sanctions aim to compel them to obey.

In Article 84, if the notary is found guilty of violating certain clauses and the same type of sanction is dissolved in other clauses, then there are 2 (two) types of civil sanctions against the notary with the following contents: Evidence as a type of contract with a notary is legally invalid. Due to the existence of this notary contract, many parties feel disadvantaged by the repayment of fees, compensation and interest to the notary.

Notaries are supervised by a team of supervisors and a board of honor, not only for the purpose of enforcing the notary's Code of Ethics, but also for broader purposes; even if the notary meets as many requirements as required by law in carrying out his duties, this is done to protect the notary. This is as stated in Article 6.

\section{Sanction}

\section{Article 6}

1. The sanctions imposed on members who violate the Code of Ethics can be in the form of:
a. Warning;
b. Warning;
c. chorsing (temporary dismissal) from membership of the Association;
d. Onzetting (dismissal) from membership of the Association;
e. Disrespectful dismissal from membership of the Association.

2. The imposition of sanctions as described above for members who violate the Code of Ethics are adjusted to the quantity and quality of violations committed by the member.

3. The Central Honorary Council has the authority to decide and impose sanctions for violations of moral norms or behavior that degrades the dignity of notaries, or actions that can reduce public trust in notaries.

4. Violations of the Code of Ethics committed by other people (who are currently in the position of notary public), may be subject to reprimands and / or warnings.

5. The Honorary Council's decision in the form of a warning cannot be appealed.

6. Decisions of the Honorary Council of the Council / Regional Honorary Regions in the form of temporary notification or honorific dismissal or dishonorable discharge from the membership of the association may be appealed to the Central Honorary Council.

7. Decisions of the first level of the Central Honorary Council in the form of suspension or honorific dismissal or dishonorable discharge from membership of the Association may be appealed to Congress.

8. The Central Honorary Council also has the authority to provide recommendations accompanied by proposals for dismissal as a notary to the Minister of Law and Human Rights of the Republic of Indonesia. 


\section{Procedures for Enforcing the Code of Ethics}

Part One Supervision

\section{Article 7}

Supervision of the implementation of the Code of Ethics is carried out in the following ways:

a. At the first level by the Regional Management of the Indonesian Notary Association and the Regional Honorary Council;

b. At the appeal level by the Regional Board of the Indonesian Notary Association and the Regional Honorary Council;

c. At the last level by the Central Board of the Indonesian Notary Association and the Central Honorary Council.

\section{The Second Part}

\section{Examination and Imposing of Sanctions}

\section{Facts of Alleged Violation}

\section{Article 8}

1. The Regional Honorary Council / Regional Honorary Council / Central Honorary Council may seek facts on the alleged Code of Ethic Violation by Association members on their own initiative or after receiving written complaints from Association members or other people accompanied by convincing evidence that there has been an alleged Code of Conduct Violation. by members of the Association.

2. Violation or receipt of a complaint which is first examined by one Honorary Council, may no longer be examined by another Honorary Council.

\section{Examination and Imposition of Sanctions at the First Level \\ Article 9}

1. The Regional Honorary Council / Regional Honorary Council / Central Honorary Council after finding the facts of the alleged Code of Conduct Violation as referred to in Article 8 above, not later than 14 (fourteen) working days the examining Honor Council is obliged to summon the member who is examining it in writing. concerned to ensure the violation of the Code of Ethics by members of the association and to provide opportunities for those concerned to provide explanations and defense. The summons are sent no later than 14 (fourteen) working days before the date of examination.

2. In the event that the summoned member is not present on the predetermined date, the examining Honorary Council will recall the second time not later than 14 (fourteen) working days after the first summoning.

3. In the event that the summoned member is not present at the second summoning, the examining Honorary Council will recall the third time at the latest within 14 (fourteen) working days after the second summoning.

4. If after the third summons (3) it is evident that they are still absent, then the Honorary Council which is examining them will continue to convene and determine the decision and / or imposition of sanctions as stipulated in Article 6 of the Code of Ethics.

5. Based on the results of the examination, an examination report signed by the member concerned and the examining Honorary Council shall be prepared. In the event that the member concerned is not willing to sign the examination report, it is sufficient for the examination report to be signed by the examining Honorary Council.

6. The Honorary Council which investigates, no later than 30 (thirty) working days after the date of the last trial, is obliged to make a decision on the results of the examination as well as determine sanctions against the offender if it is proven that there is a violation 
as regulated in Article 6 of the Code set forth in a Decree.

7. If the member concerned is not proven to have committed a violation, then the member shall be reinstated by a Decree of the Honorary Council examining it.

8. The examining Honorary Council is obliged to send the Decree to the member being examined with a registered letter and copies thereof to the Central Executive, the Central Honorary Council, the Regional Administrators, the Regional Honorary Councils, the Regional Administrators and the Regional Honorary Councils.

9. In the event that a Sanction decision is decided by and in the Congress, it must be notified by the Congress to the member being examined by registered letter and a copy thereof to the Central Executive, Central Honorary Council, Regional Administrators, Regional Honorary Council, Regional Administrators and Regional Honorary Councils.

10. Examination and decision-making at the hearing, the Honorary Council that examines must:

a. Keep respecting and upholding the dignity of the members concerned;

b. Always maintain a family atmosphere;

c. Keep everything it finds a secret.

11. The examination session is carried out in private, while the reading of the decision is carried out openly.

12. The hearing of the Honorary Council is valid if attended by more than $1 / 2$ (one half) of the number of members. If at the opening of the trial the number of quorum is not reached, the trial will be postponed for 30 (thirty) minutes. If after the postponement of the time the quorum has not been reached, then the trial is considered valid and can make a valid decision.

13. Each member of the examining Honorary Council has the right to cast one vote.

14. If at the regional management level a Regional Honorary Council has not yet been formed, then the duties and powers of the Regional Honor Council will be delegated to the Regional Honorary Council.

\section{Examination and Imposing Sanctions at the Appeal Level}

\section{Article 10}

1. An appeal request is made by the member concerned within 30 (thirty) working days, after the date of receipt of the Decree on the imposition of sanctions from the Regional Honorary Council / Regional Honorary Council.

2. An appeal request is sent by registered letter or sent directly by the member concerned to the Central Honorary Council and copies thereof to the Central Executive, Regional Administrators, Regional Honorary Councils, Regional Administrators and Regional Honorary Councils.

3. The Honorary Council decides the sanction at the latest within 14 (fourteen) working days after receiving a copy of the appeal request is obliged to send all copies / photocopies of examination documents to the Central Honorary Council.

4. After receiving the request for an appeal, the Central Honorary Council shall summon the member who submitted the appeal, not later than 14 (fourteen) working days after receiving the application for his statement to be heard and given the opportunity to defend himself in the session of the Central Honorary Council.

5. The Central Honorary Council is obliged to decide on the appeal application by no later than 30 (thirty) working days after the member concerned has been examined at the last session.

6. If the summoned member is not present, the Central Honorary Council will still decide within the time specified in paragraph (5) above. 
7. The Central Honorary Council is obliged to send the Decree to the member being examined by registered letter and a copy thereof to the Central Executive, Regional Administrators, Regional Honorary Councils, Regional Administrators and Regional Honorary Councils, not later than 14 (fourteen) working days after the date of the letter. Decision.

8. In the event that an appeal is submitted to the Congress, the request for appeal shall be made by the member concerned within 30 (thirty) working days before the Congress is held.

9. Appeals are sent by registered letter or sent directly by the member concerned to the Presidium of the Congress through the Secretariat of the Central Executive and copies thereof to the Central Executive, Central Honorary Council, Regional Administrators, Regional Honorary Councils, Regional Administrators and Regional Honorary Councils.

10. The Honorary Council decides the sanction at the latest within 14 (fourteen) working days after receiving a copy of the appeal request is obliged to send all copies / photocopies of examination files to the Presidium of the Congress through the Secretariat of the Central Executive.

11. The Congress is obliged to schedule an examination of members who submit an appeal to be heard and given the opportunity to defend themselves in the Congress.

12. Congress is obliged to decide on an appeal in that Congress.

13. If the member making the appeal does not appear in Congress, Congress will still decide on the appeal.

14. The Congress, through the Central Honorary Council, is obliged to send said Decree to the members being examined by registered letter and copies thereof to the Central Executive, Regional Administrators, Regional Honorary Councils, Regional Administrators and Regional Honorary Councils.

15. The sanction decision as intended in Article 6 paragraph (1) has permanent legal force in terms of:

a. Members are subject to sanctions in the form of a warning;

b. Members are subject to sanctions in the form of temporary dismissal or dismissal with respect or disrespectful dismissal from membership of the Association, accept the decision and do not file an appeal within the stipulated time;

c. The Central Honorary Council / Congress has issued an appeal sanction decision.

Amend Article 11 so that it reads as follows:

\section{Article 11}

1. The provisions and procedures for examining alleged violations committed by Members and other people (who are currently carrying out the position of Notary), will be further regulated in the Central Honorary Council Regulations.

2. Imposition of sanctions for violation of the Code of Ethics in Article 3 and Article 4 will be regulated in the Central Honorary Council Regulation.

The provisions of Article 12 paragraph (2) are amended so that Article 12 reads as follows: 


\section{Part Three}

\section{Recording of Sanctions for Violation of the Code of Ethics}

\section{Article 12}

The Central Executive is obliged to record in a book a list of Association members on every decision of the Regional Honorary Council / Regional Honorary Council / Central Honorary Council / Congress which has permanent legal force.

The purpose of this series of activities is of course to have an embarrassing effect on the notary public, so that it is deterring and does not repeat actions / activities that violate the code of ethics. Other public notaries also need to ensure that the Code of Ethics is not violated so that enforcement efforts can be made. And of course, behind these strict sanctions, the public will appreciate the efforts of the honorary council to take firm action against notaries who violate the code of ethics. So that public confidence in this profession grows by itself.

\section{Conclusion}

The existence of a notary promotion prohibition lies in the fact that a notary as a public service position requires the trust of the person he serves, and the notary's existence is not for the personal benefit of the appointed person. So that notaries are obliged to maintain their dignity. There is a prohibition on promotion for notaries because the notary position is a position that provides services to the public, where the notary requires the trust of the community he serves; and again, the notary's existence is not for the personal benefit of the person being served, so that a notary is obliged to uphold the nobility of his dignity. In promotions that are informative and reminders, it is permissible. Among them are providing information and knowledge about legal issues; case review of legal problems in the world of notary; provides examples of notary deeds. Examples of types of promotion that are prohibited include: trying to get someone to move from another notary to him, whether the effort is directed directly at the client concerned or with someone else's intermediary; malign fellow notary colleagues or demonize or blame deeds drawn up by notary colleagues; sending "salesmen" to various places or locations to collect clients or deeds; send a wreath for any incident and to anyone with the name of the notary public, be it limited public or unlimited public.

It is necessary to introduce changes to the provisions of the Code of Ethics of the Honorary Council which are no longer in line with developments in science and technology, especially in relation to the prohibition of promotion to notary positions. Strict and binding sanctions are required by the Honorary Council, as the creator of the mandate, to enforce the Notary Code of Ethics. Sanctions' arrangements in the Code of Conduct need to be revised, because they cannot depend solely on an Honorary Council decision where the assessment can be highly subjective.

\section{References}

Cahyanti, N. (2018). Sanksi Terhadap Notaris Yang Melakukan Tindak Pidana Menurut Peraturan Perundang-Undangan Di Indonesia. Fakultas Hukum UNISSULA.

Diani, R., \& Agus, A. (2019). Analisis Yuridis Perjanjian Kerjasama Antara Notaris Dengan Bank Ditinjau Dari Undang-Undang Nomor 2 Tahun 2014 Tentang Jabatan Notaris Dan Kode Etik Notaris. Jurnal Hukum Tri Pantang, 5(2), 45-54.

Dwi, I. Y. (2013). Memahami Berbagai Etika Profesi \& Pekerjaan. Yogyakarta: medpress Digital. 
Ghansham Anand, S. H., \& Kn, M. (2018). Karakteristik Jabatan Notaris di Indonesia. Prenada Media.

Hadjon, P. M. (2017). Penegakan Hukum Administrasi Dalam Kaitannya Dengan Ketentuan Pasal 20 Ayat 3 Dan 4 Uu No. 4 Th. 1982 Tentang Ketentuan Ketentuan Pokok Pengelolaan Lingkungan Hidup. Yuridika, 11(1).

Handayani, T. U., Suryaningtyas, A., \& Mashdurohatun, A. (2018). Urgensi Dewan Kehormatan Notaris Dalam Penegakan Kode Etik Notaris Di Kabupaten Pati. Jurnal Akta, 5(1), 51-64.

Kie, T. T. (2011). Studi Notaris dan Serba-Serbi Praktek Notaris, Jakarta, PT. Ichtiar Baru Van Hoeve.

Moechthar, O. (2017). Dasar-dasar Teknik Pembuatan Akta. Airlangga University Press.

Notaris, P. P. I. (2013). Jati Diri Notaris Indonesia. Gramedia Pustaka Utama.

Rachmawati, S., \& Fadli, M. (2019). Pemuatan Foto dan Papan Nama Notaris di Instagram sebagai Bentuk Pelanggaran Kode Etik Notaris di Kota Malang. Jurnal Ilmiah Pendidikan Pancasila Dan Kewarganegaraan, 4(1), 162-168.

Suhrawardi, L. K. (2008). Etika Profesi Hukum, Cetakan Kelima. Sinar Grafika, Jakarta. 